\title{
MELT RATE IMPROVEMENT FOR THE DWPF: Higher Waste Loading Testing
}

\author{
T.H. Lorier \\ P.L. McGrier
}

Westinghouse Savannah River Company

Savannah River Technology Center

Aiken, SC

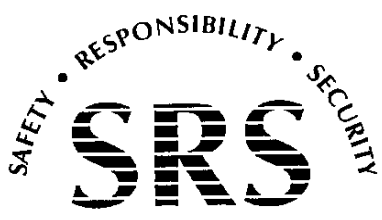


This document was prepared in conjunction with work accomplished under Contract No. DE-AC09-96SR18500 with the U. S. Department of Energy.

\section{DISCLAIMER}

This report was prepared as an account of work sponsored by an agency of the United States Government. Neither the United States Government nor any agency thereof, nor any of their employees, makes any warranty, express or implied, or assumes any legal liability or responsibility for the accuracy, completeness, or usefulness of any information, apparatus, product or process disclosed, or represents that its use would not infringe privately owned rights. Reference herein to any specific commercial product, process or service by trade name, trademark, manufacturer, or otherwise does not necessarily constitute or imply its endorsement, recommendation, or favoring by the United States Government or any agency thereof. The views and opinions of authors expressed herein do not necessarily state or reflect those of the United States Government or any agency thereof.

This report has been reproduced directly from the best available copy.

Available for sale to the public, in paper, from: U.S. Department of Commerce, National Technical Information Service, 5285 Port Royal Road, Springfield, VA 22161, phone: (800) 553-6847, fax: (703) 605-6900

email: orders@ntis.fedworld.gov

online ordering: http://www.ntis.gov/help/index.asp

Available electronically at http://www.osti.gov/bridge

Available for a processing fee to U.S. Department of Energy and its contractors, in paper, from: U.S. Department of Energy, Office of Scientific and Technical Information, P.O. Box 62, Oak Ridge, TN 37831-0062,

phone: (865)576-8401,

fax: (865)576-5728

email: $\underline{\text { reports@ adonis.osti.gov }}$ 


\title{
MELT RATE IMPROVEMENT FOR THE DWPF: Higher Waste Loading Testing
}

\author{
T.H. Lorier \\ P.L. McGrier
}

Westinghouse Savannah River Company

Savannah River Technology Center

Aiken, SC under that contract. 
Immobilization Technology Section

Savannah River Technology Center

Westinghouse Savannah River Company

\begin{tabular}{|c|c|c|c|}
\hline $\begin{array}{l}\text { Task Title: DWPF Melt Rate } \\
\text { Testing (Higher Waste Loading } \\
\text { Testing) }\end{array}$ & & $\begin{array}{l}\text { TTR Number: } \\
\text { HLW/DWPF/TTR- } \\
\text { 02-0001, Rev. } 1\end{array}$ & $\begin{array}{l}\text { TTR Date: } \\
\text { 12/17/01 }\end{array}$ \\
\hline $\begin{array}{l}\text { Task Leader: } \\
\text { T.H. Lorier }\end{array}$ & Signature: & $\begin{array}{l}\text { Organization: } \\
\text { ITS }\end{array}$ & Date: \\
\hline $\begin{array}{l}\text { Technical Reviewer: } \\
\text { D.C. Witt }\end{array}$ & Signature: & $\begin{array}{l}\text { Organization: } \\
\text { ITS }\end{array}$ & Date: \\
\hline $\begin{array}{l}\text { Technical Reviewer: } \\
\text { D.K. Peeler }\end{array}$ & Signature: & $\begin{array}{l}\text { Organization: } \\
\text { ITS }\end{array}$ & Date: \\
\hline $\begin{array}{l}\text { Level } 3 \text { Manager: } \\
\text { E.W. Holtzscheiter }\end{array}$ & Signature: & $\begin{array}{l}\text { Organization: } \\
\text { ITS }\end{array}$ & Date: \\
\hline $\begin{array}{l}\text { Level } 4 \text { Manager: } \\
\text { S.L. Marra } \\
\end{array}$ & Signature: & $\begin{array}{l}\text { Organization: } \\
\text { ITS }\end{array}$ & Date: \\
\hline
\end{tabular}


Immobilization Technology Section

Savannah River Technology Center

Westinghouse Savannah River Company

\section{GLOSSARY}

$\begin{array}{ll}\text { cent } & \text { Centroid } \\ \text { DOE } & \text { Department of Energy } \\ \text { DWPF } & \text { Defense Waste Processing Facility } \\ \text { HLW } & \text { High Level Waste } \\ \text { ITS } & \text { Immobilization Technology Section } \\ \text { LLW } & \text { Low Level Waste } \\ \text { LMR } & \text { Linear Melt Rate } \\ \text { MRF } & \text { Melt Rate Furnace } \\ \text { SB } & \text { Sludge Batch } \\ \text { SMRF } & \text { Slurry-fed Melt Rate Furnace } \\ \text { SRAT } & \text { Sludge Receipt Adjustment Tank } \\ \text { SRTC } & \text { Savannah River Technology Center } \\ \text { TFA } & \text { Tanks Focus Area } \\ \text { TIM } & \text { Task Integration Manager } \\ \text { T }_{\text {L }} & \text { Liquidus Temperature } \\ \text { WL } & \text { Waste Loading }\end{array}$


Immobilization Technology Section

Savannah River Technology Center

Westinghouse Savannah River Company

This page intentionally left blank. 
Immobilization Technology Section

Savannah River Technology Center

Westinghouse Savannah River Company

\section{ACKNOWLEDGEMENTS}

The authors would like to acknowledge Douglas Witt, David Peeler, Michael Stone, and Tim Jones for their technical guidance and reviews; Mary Moss, Tony Burckhalter, Vickie Williams, Sammie King, and Jon Duvall for their patience and hard work; Curtis Sexton and Gary Dobos for glass-shop work; and William Holtzscheiter (TFA TIM for Immobilization) and Sharon Marra for management and guidance. This study was co-funded by the Department of Energy's Office of Science and Technology through the Tanks Focus Area and through the Defense Waste Processing Facility. Westinghouse Savannah River Company is operated for the U.S. Department of Energy under Contract No. DE-AC09-96SR18500. 
Savannah River Technology Center

Westinghouse Savannah River Company

\section{Contents}

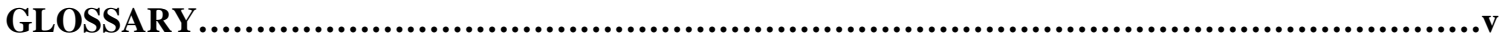

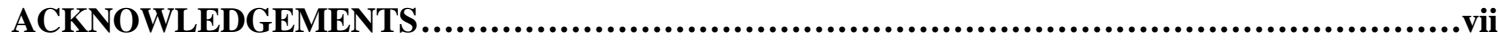

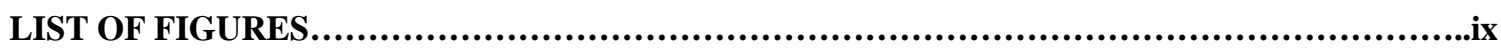

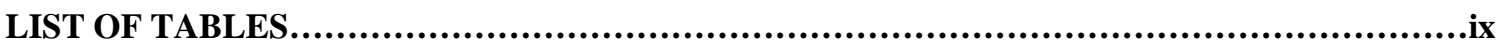

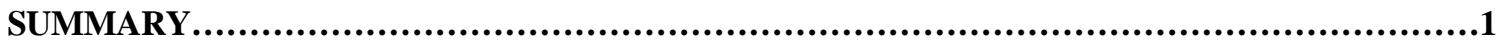

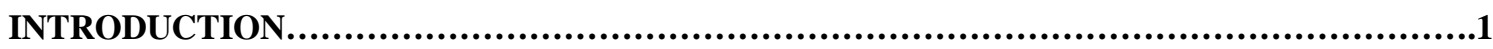

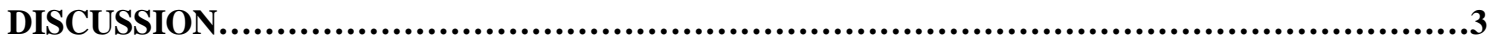

CONCLUSIONS.....................................................................................9

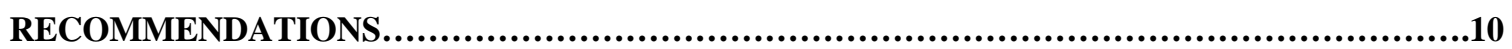

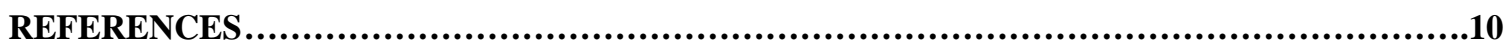


Immobilization Technology Section

Savannah River Technology Center

Westinghouse Savannah River Company

\section{LIST OF FIGURES}

Figure S.1. $\quad$ Plot of Waste Throughput for Frit 320 with SB2 as a Function of.................... Waste Loading (Data from Table 3).

Figure 1. Temperature Profiles of Each Higher Waste Loading Test...........................

Figure 2. Sectioned Beakers of the Higher Waste Loading Tests..............................6

Figure 3. Plot of the Melt Rate Data for Frit 320 with SB2 as a Function of................... 8

Waste Loading (Data from Table 2).

Figure 4. Plot of Waste Throughput for Frit 320 with SB2 as a Function of....................

Waste Loading (Data from Table 3).

\section{LIST OF TABLES}

Table 1. Semi-quantitative Melt Rates for Each Waste Loading..........................

Table 2. $\quad$ Waste Throughput as a Function of Waste Loading............................... 


\section{SUMMARY}

This report describes scoping investigations into higher waste loading (WL) effects on melt rate for sludge batch 2 (SB2). Previous baseline tests in support of the melt rate program were performed at 25\% WL. Waste loadings for these higher waste-loading tests ranged from $27 \%$ to $41 \%$ (in $2 \%$ increments), and all utilized Frit 320 and simulated SB2 SRAT product. The 41\% WL bounds projected maximum waste loadings based on implementation of the new liquidus temperature $\left(\mathrm{T}_{\mathrm{L}}\right)$ model. The results and trends of these scoping studies indicate that within the WL range tested, melt rate decreases as WL increases (see Table 2 and Figure 3). However, the net effect is that the amount of waste processed per hour (throughput) increases relative to the $25 \% \mathrm{WL}$ baseline up to $35 \% \mathrm{WL}$, based on the linear melt rate data (see Table 3 and Figure S.1). Operation beyond 37\% WL may not be advantageous unless the cost savings associated with the reduced number of canisters outweighed the throughput reduction.

Figure S.1 Plot of Waste Throughput for Frit 320 with SB2 as a Function of Waste Loading (Data from Table 3).

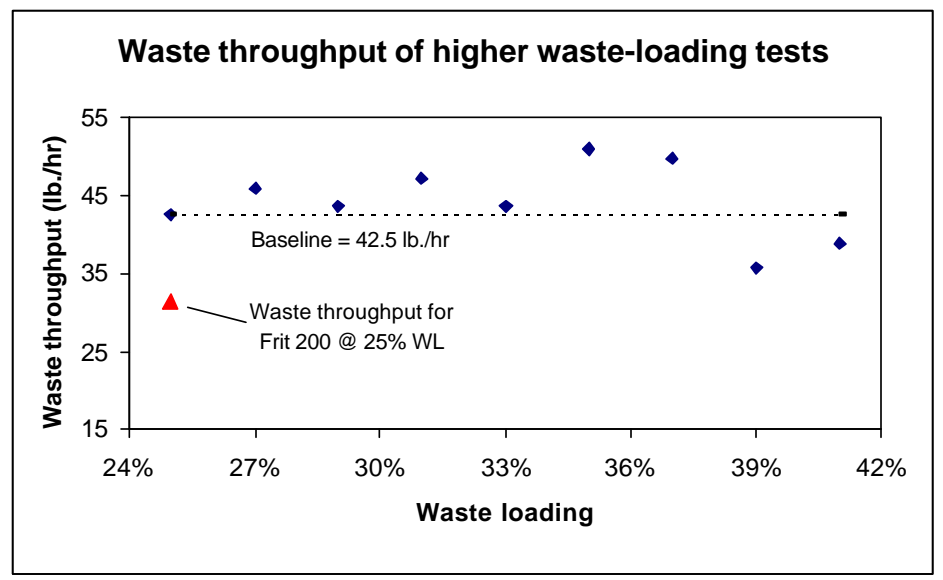

\section{INTRODUCTION}

Fundamental work is needed to better understand the effects of feed chemistry, rheology, and process chemistry on melting behavior for Department of Energy (DOE) high-level waste (HLW) glasses. Melt rate furnace testing is being conducted with the goal of improving melt rate, but also to establish an improved understanding of parameters controlling melt rate. Presently, dry-fed melt rate furnace (MRF) tests are being used to obtain relative melt rate behavior, and a slurry-fed melt rate furnace (SMRF) is being developed to increase confidence in the present tests and to reduce the risk that no major differences are observed from dry-fed to slurry-fed systems. Melting behavior, foaming, and changes to the acid addition chemistry will be evaluated using both melt rate furnaces, while the effects of slurry feeding and the associated cold-cap chemistry will be assessed with the SMRF.

Glass melting is a complex process that involves a number of reactions and transformations, and its rate or behavior can only be described considering all related processing properties. Given that, one needs to establish or identify the relevant processes that impede melt rate for a given system and focus research and development efforts on potential mitigation techniques. Melt rate is defined as how quickly feed materials are converted to a liquid melt (i.e., the rate of the batch-to-glass conversion process) which is ultimately linked to glass throughput.

The current focus of this research is to enhance the basic understanding of the role of glass chemistry and/or acid addition strategy changes on the overall melting process for the Defense Waste Processing 
Facility (DWPF). More specifically, by controlling the chemistry of the incoming feed materials (e.g., in particular the frit composition for a given sludge) or by adjusting chemical processing strategies (e.g., formic or nitric acid relative to the current flowsheet), the conversion rate of slurry-fed raw materials into a molten state can be increased. Intermediate reaction products and/or the development of an insulating foamy layer which can impede the melting rate can be avoided by altering the reaction pathway within the cold cap. If successful, the result is an enhanced melting process which increases throughput without compromising the quality of the final waste form.

Increased melting efficiencies decrease overall operational costs by reducing the immobilization campaign time for a particular waste stream and the entire DWPF process. For melt rate limited systems, a small increase in melting efficiency translates into significant savings by reducing operational costs. For example, a 10\% increase in melter throughput (melt rate) would reduce the DWPF's overall processing time by almost two years, translating to an $\$ 860 \mathrm{M}$ savings in life cycle costs (Savannah River Site High Level Waste System Plan, Rev. 12).

A study performed in 2001 concluded that a change from Frit 200 to Frit 320 would increase the melt rate in the DWPF for SB2, without decreasing the WL (Lambert et. al, 2001). Since those initial crucible-scale and 4" dry-feed melt rate furnace (MRF) tests, Frit 320 has been tested in the Minimelter (Miller, 2002) and further in the 4" MRF (Stone and Josepsh, 2001), all of which showed similar trends in melt rate. For this particular study however, higher WL of SB2 with Frit 320 was the focus. Frit 320 was tested in the 4" MRF for waste loadings ranging from 27 to $41 \%$.

Increasing the WL in the glass is desirable to reduce the amount of glass generated and ultimately the number of canisters. Dramatic cost savings can also be realized through increased waste loadings. It has been estimated that a $1 \%$ increase in WL would translate into more than $\$ 330 \mathrm{M}$ total cost savings to the DWPF (assuming the same fixed annual operating cost described above and a 1\% increase from $29 \%$ to $30 \% \mathrm{WL}$ ). Given that WL has typically been limited by predictions of $\mathrm{T}_{\mathrm{L}}$, the Savannah River Technology Center (SRTC) developed a new $\mathrm{T}_{\mathrm{L}}$ model. This new model allows for higher waste loadings to be achieved not only for SB2, but for future sludge batches as well (Brown et. al, 2001). Implementation of this new $\mathrm{T}_{\mathrm{L}}$ model in the DWPF process control system is currently in progress. The effects of implementing the new $\mathrm{T}_{\mathrm{L}}$ model and Frit 320 offer a significant advantage in terms of WL projections for SB2 - increasing from a maximum WL of $\sim 31 \%$ with the old $\mathrm{T}_{\mathrm{L}}$ model and Frit 200 to $\sim 39 \%$ when using the new $\mathrm{T}_{\mathrm{L}}$ model and Frit 320 . It should be noted that the WL projections are based on nominal sludge compositions and do not take into account any compositional variation in the sludge.

Current plans are to implement Frit 320 in $4^{\text {th }}$ quarter FY02 without a change in WL to assess the impact of this frit change on melt rate relative to Frit 200. Once that has been established, plans are to increase waste loadings in incremental steps up to the point allowed by the new $T_{L}$ model. Frit 320 was developed for lower waste loadings (25\%) and prior to development of the new liquidus model, and may not be the preferred frit for higher waste loadings. For a specific frit, lower melt rates are generally expected at higher waste loadings. Therefore, the work described in this report was undertaken to provide an initial evaluation of the effect of increased WL on melt rate and overall waste throughput.

\section{DISCUSSION}

All tests for the higher waste-loading series were completed with melter feed prepared from SB2 simulant. The feed preparation process converted the Tank 8 and Tank 40 blend into feed for the 4" MRF. The feed preparation process was composed of three steps: 1) adding trim chemicals to the sludge simulant, 2) processing the sludge simulant through a Sludge Receipt Adjustment Tank (SRAT) process, and 3) combining the SRAT product with Frit 320 and removing water by drying in an oven. The amounts of the SRAT product and Frit 320 in Step 3 were based on the \% WL being evaluated. All feed preparation methods are discussed in Stone and Lambert (2001). 
The melt rate furnace test methods (equipment description, equipment operation, etc.) are discussed in Stone and Josephs (2001). For each higher waste-loading test performed, four thermocouples were placed in the beaker at 1/2", 1", 2", and 5" from the bottom. For consistency and comparison purposes, the run time was 42 minutes for each run, this time being determined by testing performed in 2001 (Stone and Josephs, 2001). Figure 1 shows the temperature profiles generated for each of the waste loadings evaluated.

Figure 1. Temperature Profiles of Each Higher Waste Loading Test.
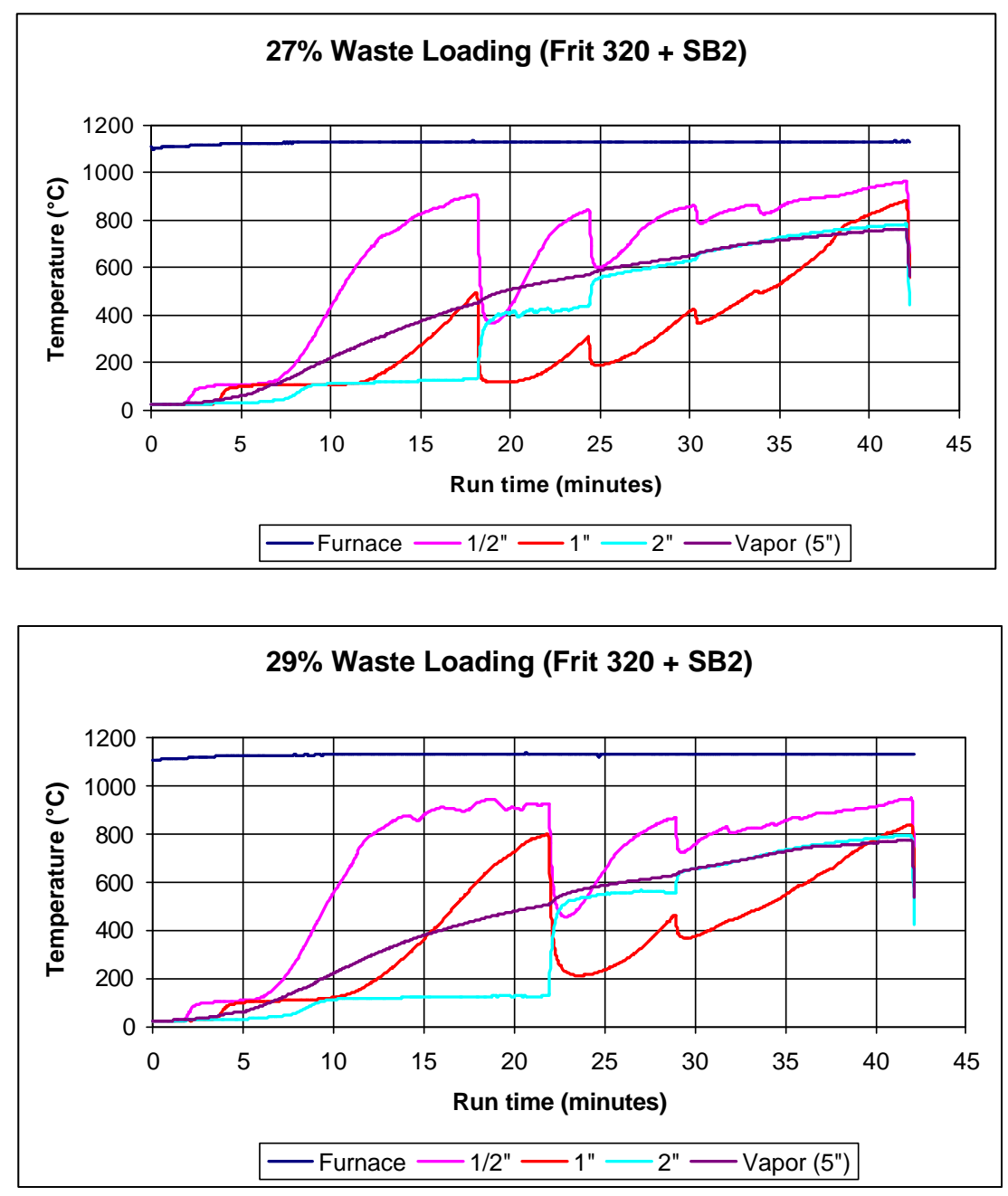
Immobilization Technology Section

WSRC-TR-2002-00344

Savannah River Technology Center

Westinghouse Savannah River Company

Figure 1 (cont'd)
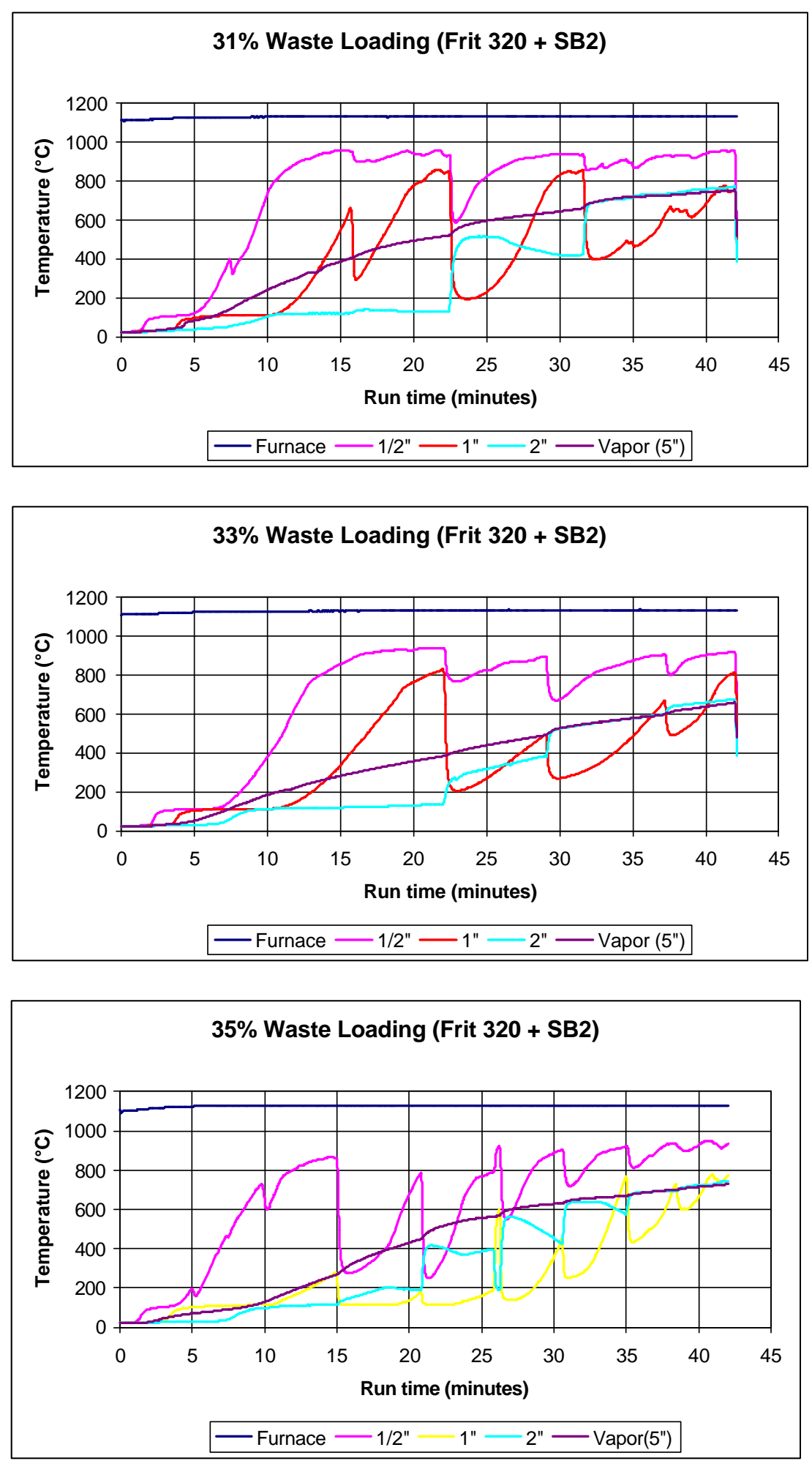
Immobilization Technology Section

WSRC-TR-2002-00344

Savannah River Technology Center

Westinghouse Savannah River Company

Figure 1 (cont'd)
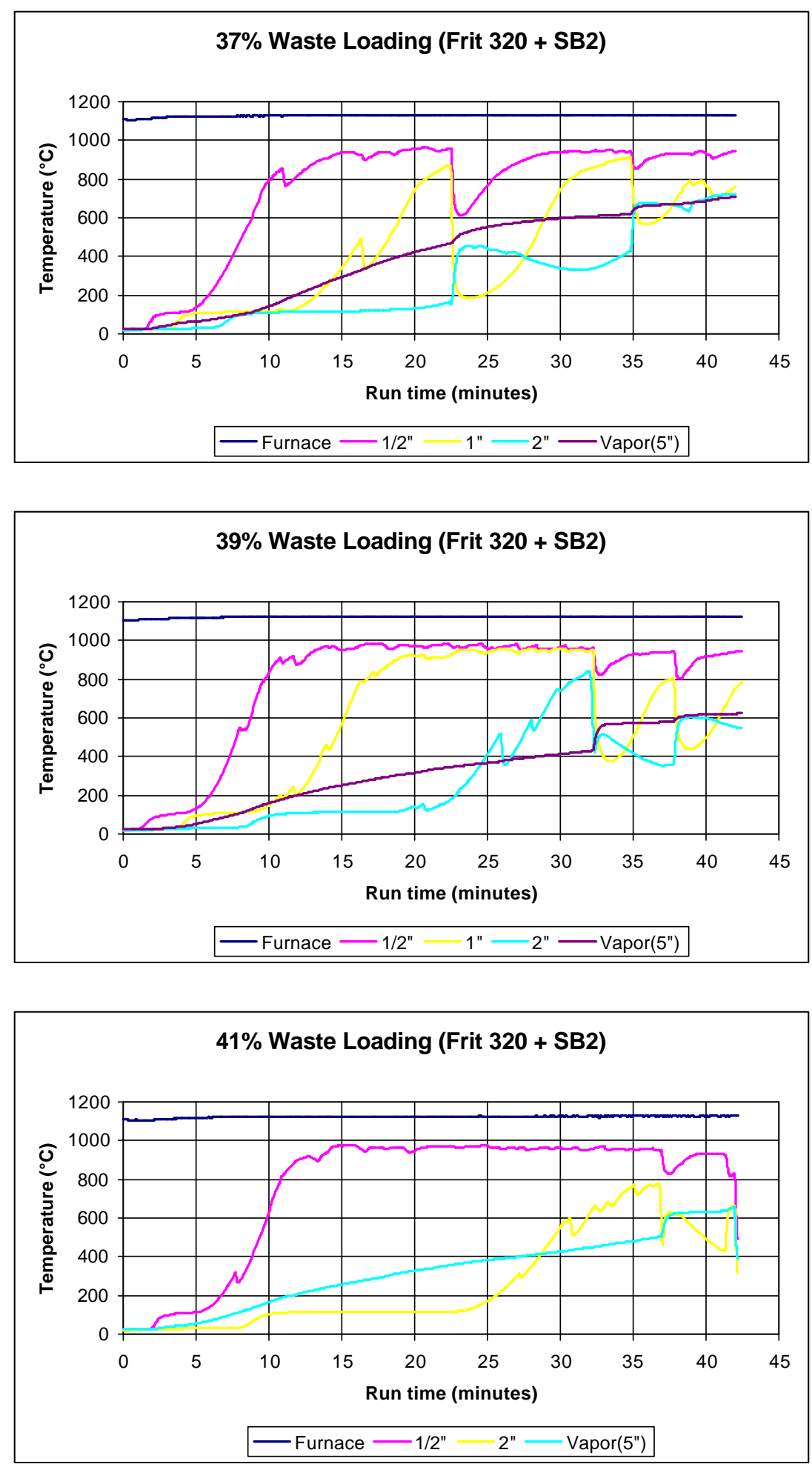
These temperature profiles were very useful in determining the melting and cold cap behaviors for each batch. For instance, the plots for waste loadings up to $35 \%$ show there is significant rise and fall in temperature throughout the entire run, especially at heights of $1 / 2$ " and 1 " from the bottom of the beaker. This would indicate that heat is being transferred through the batch well, and the off-gases being produced are escaping past the cold cap. Beginning at $37 \% \mathrm{WL}$, and especially at $39 \%$ and $41 \% \mathrm{WL}$, there is a significant rise in temperature which does not dissipate quickly, indicating significant volume expansion and/or foam formation. This creates an insulating effect, which greatly slows down the transfer of heat to the unreacted material above. The cold cap and melting behavior of the batch are adversely affected, and more foam and bridging ultimately result. Bridging is when an air gap develops between the glass pool and the melting feed and does not dissipate rapidly (Stone and Josephs, 2001).

Examples of some of these phenomena are shown in Figure 2. The first indication of unreacted feed after 42 minutes arose in the 31\% WL run (see photo in Figure 2). As the WL increased, more unreacted feed remained on top of the batch after 42 minutes. Also, larger bubbles remained trapped during higher WL runs, creating an insulating layer that ultimately slowed down melt rate, resulting in less glass being produced (more unreacted batch remaining).

The method used to determine the melt rate was to measure the height of the glass pool formed during each test and divide by the run time (consistent with that used by Stone and Josephs, 2001). The beakers were sectioned in half (see Figure 2) and the height of the glass pool was measured from the bottom of the beaker to the point where the glass was no longer free of bubbles.

Figure 2. Sectioned Beakers of the Higher Waste Loading Tests.

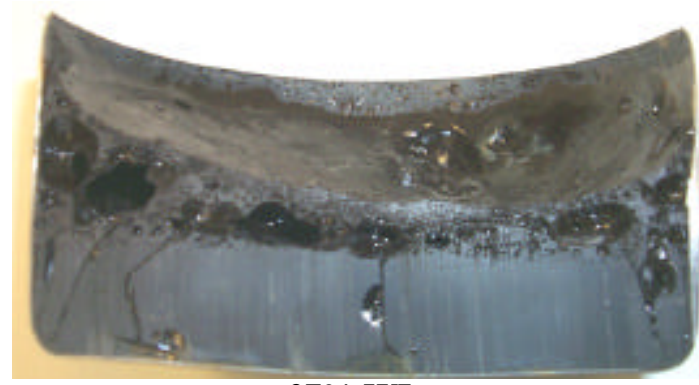

$27 \%$ WL

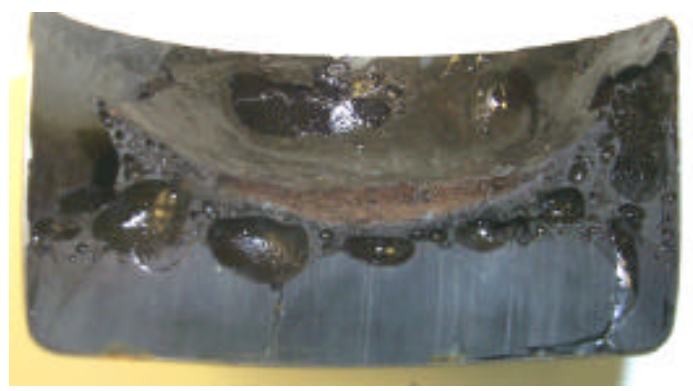

$31 \% \mathrm{WL}$

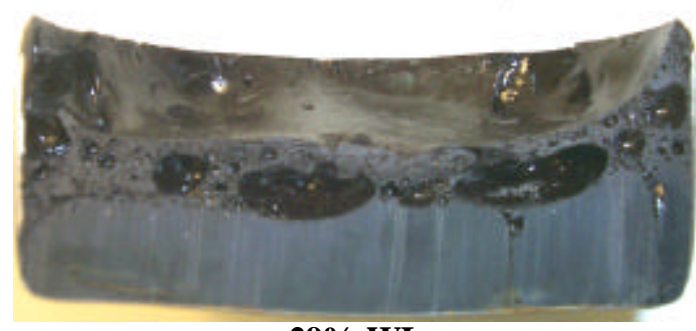

$29 \% \mathrm{WL}$

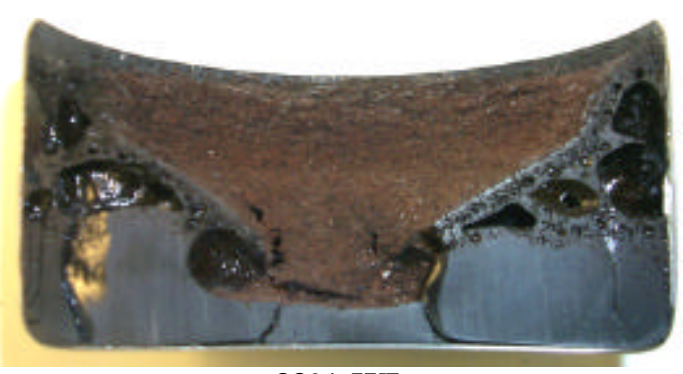

$33 \%$ WL 
Figure 2 (cont'd)

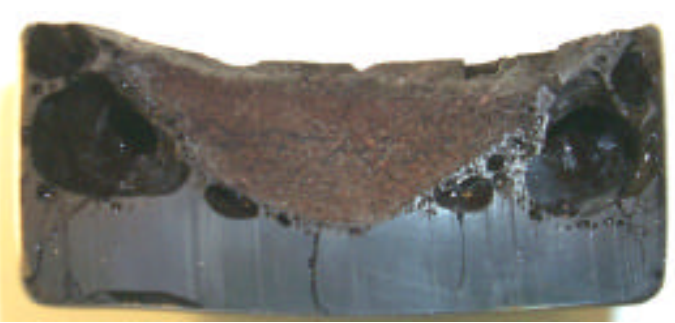

$35 \% \mathrm{WL}$

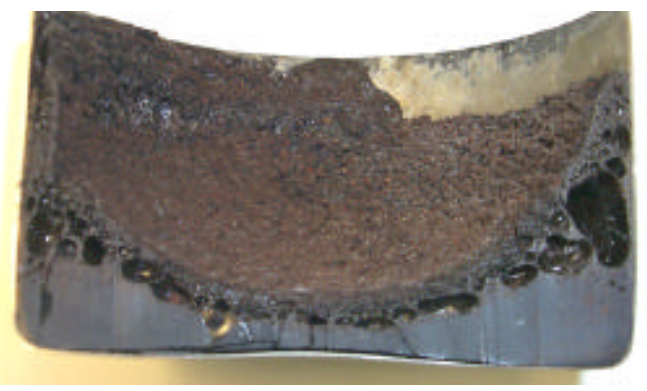

$39 \% \mathrm{WL}$

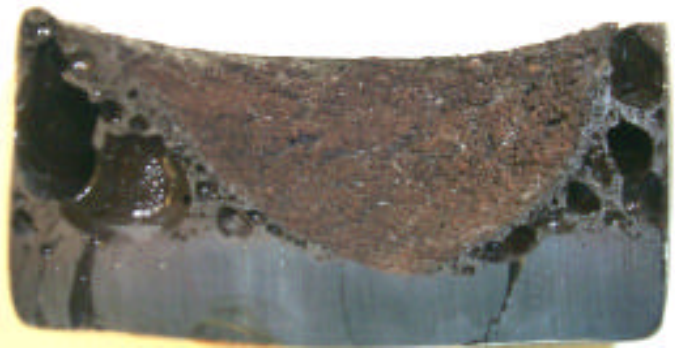

$37 \% \mathrm{WL}$

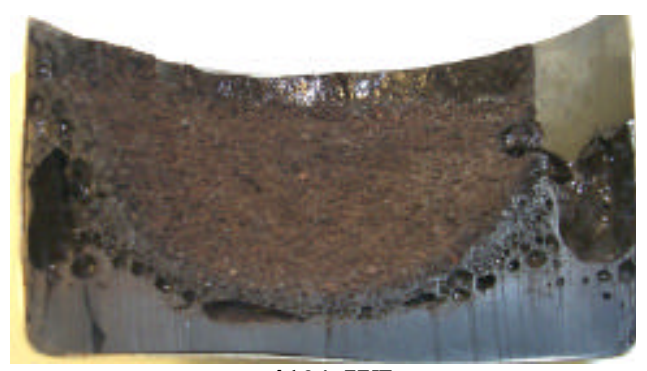

$41 \% \mathrm{WL}$

Two melt rates were calculated for each run - a linear melt rate and a volumetric melt rate. The linear method involves measuring the glass height at $1 / 4$ " intervals across the beaker, and then averaging the values to obtain an average glass pool height. The average glass pool height was divided by the run time to obtain the melt rate result in inches per hour. The volumetric method involves calculation of the volume of each concentric ring represented by the glass pool height at $1 / 4$ " intervals, and then summing the volume of the rings to obtain the volume of the glass produced during the run. The glass volume was then divided by the run time to obtain a melt rate in cubic inches per hour. This melt rate data is presented in Table 2 and Figure 3.

Table 1. Semi-quantitative Melt Rates for Each Waste Loading.

\begin{tabular}{c|c|c}
\hline $\begin{array}{c}\text { Waste } \\
\text { loading }\end{array}$ & $\begin{array}{c}\text { Linear melt rate } \\
\text { (in./hr.) }\end{array}$ & $\begin{array}{c}\text { Volumetric melt rate } \\
\left.\text { (in }^{\mathbf{3}} \mathbf{h r} .\right)\end{array}$ \\
\hline $25 \%$ & 1.04 & 12.8 \\
$27 \%$ & 1.04 & 13.1 \\
$29 \%$ & 0.92 & 12.1 \\
$31 \%$ & 0.93 & 11.7 \\
$33 \%$ & 0.81 & 12.4 \\
$35 \%$ & 0.89 & 11.6 \\
$37 \%$ & 0.82 & 10.6 \\
$39 \%$ & 0.56 & 8.8 \\
$41 \%$ & 0.58 & 8.7 \\
\hline
\end{tabular}


Figure 3. Plot of the Melt Rate Data for Frit 320 with SB2 as a Function of Waste Loading (Data from Table 2).

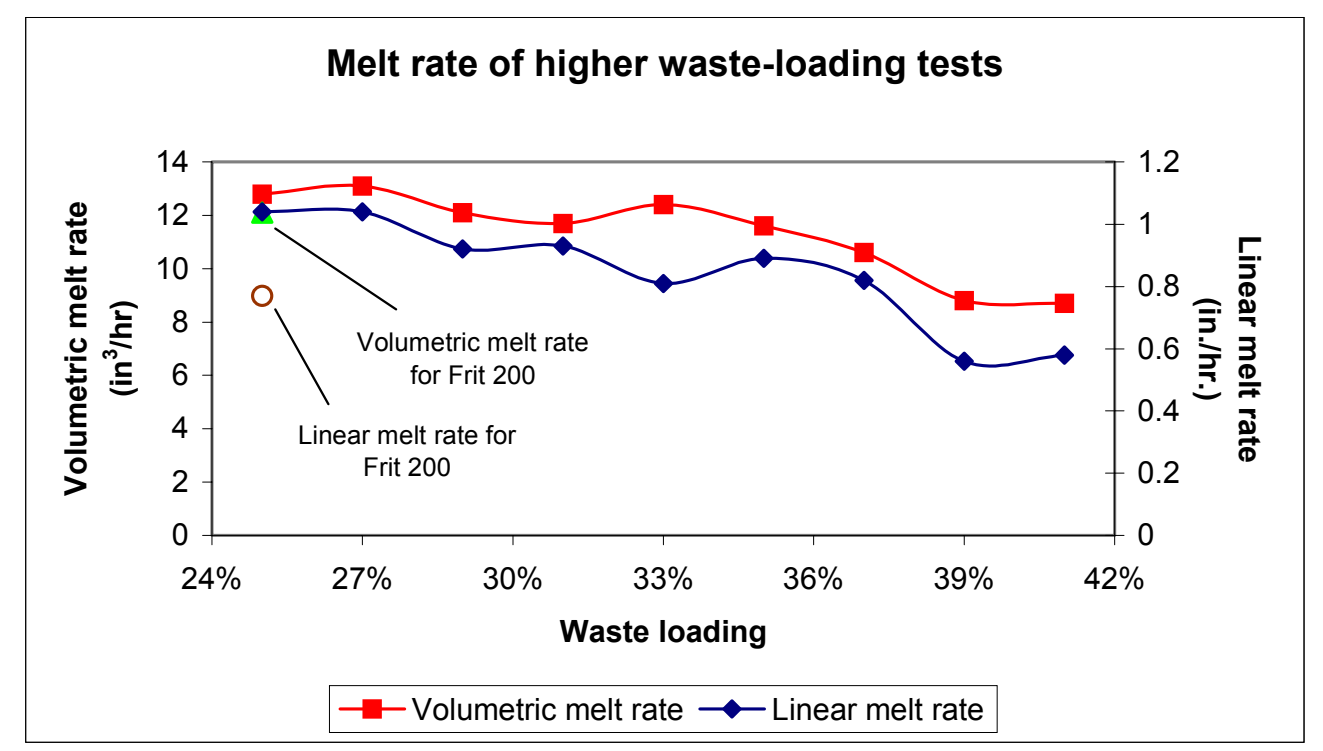

As shown by the data, the general trend is that melt rate decreases as WL increases (for both measurement techniques). By increasing the ratio of waste to frit, less flux (less alkali) is added to the system (see Figure 9 in Stone and Josephs, 2001). An increase in alkali correlates strongly to an increase in melt rate, whether it is present in the frit or in the waste (Lambert et. al, 2001). Also, the linear and volumetric melt rates for Frit 200 and SB2 at 25\% WL have been added to Figure 3 to emphasize the effect of switching from Frit 200 to Frit 320.

Even though melt rate may decrease as WL increases as indicated above, the waste throughput per unit time may not. The data in Table 3 and Figure 4 show the dependence of waste throughput on WL. Waste throughput was calculated via Equation 1, and assuming the amount of waste glass processed per hour by the DWPF is approximately 170 pounds.

$$
\text { Throughput }_{W L \# 2}=170\left(\frac{L M R_{W L \# 2}}{L M R_{25 \% W L}}\right)(W L \# 2)
$$

The waste loading of interest is WL\#2, Throughput $\mathrm{WL}_{\mathrm{L}}$ is the waste throughput at that specified waste loading, and LMR is the linear melt rate (values listed in Table 2). For example, the waste throughput at $33 \% \mathrm{WL}$ is 43.7 pounds per hour, which was calculated as follows:

$$
\text { Throughput }_{33 \% W L}=170\left(\frac{0.81}{1.04}\right)(0.33)
$$


Table 2. Waste Throughput as a Function of Waste Loading.

\begin{tabular}{c|c}
\hline Waste loading & Waste throughput (lb./hr) \\
\hline $25 \%$ & 42.5 \\
$27 \%$ & 45.9 \\
$29 \%$ & 43.6 \\
$31 \%$ & 47.1 \\
$33 \%$ & 43.7 \\
$35 \%$ & 50.9 \\
$37 \%$ & 49.6 \\
$39 \%$ & 35.7 \\
$41 \%$ & 38.9 \\
\hline
\end{tabular}

Figure 4. Plot of Waste Throughput for Frit 320 with SB2 as a Function of Waste Loading (Data from Table 3).

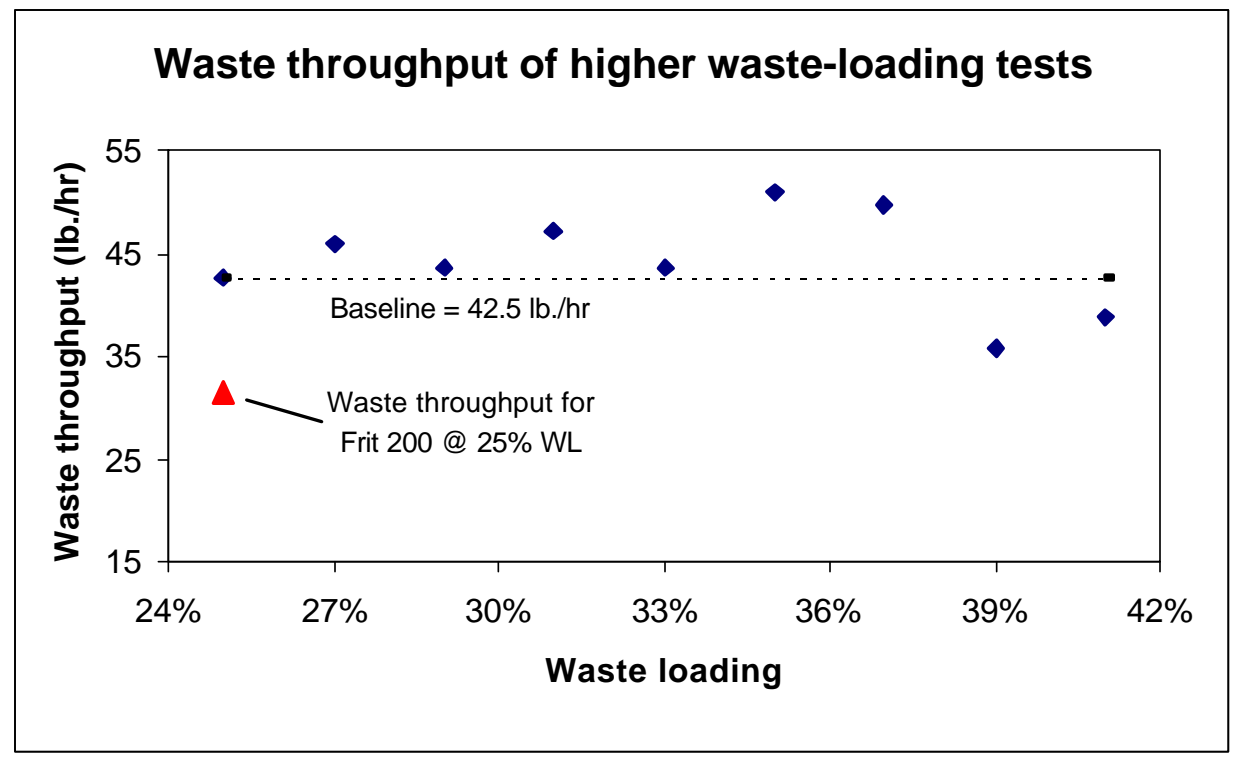

The waste throughput for Frit 200 with SB2 at 25\% WL was added to Figure 4 to show the advantage of just switching from Frit 200 to Frit 320. Also shown in Figure 4 is a dashed line indicating the baseline waste throughput for the Frit 320/SB2 system. Up to a WL of 37\%, the waste throughput is greater than the baseline value of $42.5 \mathrm{lb}$./hr. However, waste throughput values for the $39 \%$ and $41 \%$ waste loadings dip below the baseline. This trend indicates that WL can be increased for SB2 with Frit 320, but caution must be used in doing so since melt rate and overall throughput decrease at higher waste loadings. However, it should be noted that the waste throughput values for all Frit 320/SB2 waste loadings are greater than the current Frit 200 based system. To determine if operation above 37\% WL would be warranted, a cost analysis would need to be done to evaluate the competing effects of decreased throughput versus an overall reduction in the number of canisters produced.

\section{CONCLUSIONS}

As WL was increased (from 25 to 41\%) during this testing of SB2 with Frit 320, melt rate was found to decrease in the overall WL range tested and melting behavior deteriorated. Waste throughput, however, 
exceeded the $25 \%$ WL baseline case until a critical waste loading was reached, at which point melting behavior deteriorated sufficiently to significantly decrease melting rate. For the SB2/Frit 320 system, this occurred in the 37 to $39 \%$ WL range. It should be noted that the waste throughput values for all Frit 320/SB2 waste loadings are greater than the current Frit 200 based system (at 25\% WL). Selected tests with the slurry-fed melt rate furnace will be performed to verify the results of the dry-fed testing. To determine if operation above $37 \%$ WL would be warranted, a cost analysis would need to be performed to evaluate the competing effects of decreased throughput versus an overall reduction in the number of canisters produced.

\section{RECOMMENDATIONS}

1. In transitioning from Frit 200 to Frit 320 in $4^{\text {th }}$ quarter FY02, it is recommended that processing with Frit 320 begin at the same waste loading as when processing with Frit 200. Five melter volumes ( $\sim 75 \mathrm{~K}$ pounds of glass produced) should be processed at this waste loading. At this point the DWPF should then process five melter volumes each at a WL below and above that original WL (a large enough increment that the DWPF can detect and to show a noticeable difference in melt rate) in order to determine the melter's optimum level of operation. Observations of the electrode power and dome heater power, along with visual observations of the cold cap and melt behavior (use of a boroscope), should be made since higher waste loadings may have detrimental effects on waste throughput and melting behavior.

2. Although the ultimate objective is to increase both waste loading and melt rate, one should not lose sight of total waste throughput, which may require a compromise between the two controlling factors. The concept that reduced melt rates at higher waste loading is unacceptable should be tempered with an evaluation of the total waste throughput. More specifically, during an assessment of the impacts of waste loading on melt rate, decisions on frit selection or targeted waste loading should not be made solely on the relative melt rate. Conversely, a decision on waste loading should not be made solely on the liquidus model. The decision should consider the total sludge throughput per unit time.

3. Given the key criteria of waste loading and melt rate can be competing, the basis for not only developing but ultimately selecting a frit for any sludge batch is complex. It is recommended that the selection process should not be made based on a single criterion but on a collection of criteria that provide insight into the economics of pretreatment requirements, processing issues, and ultimately total number of canisters produced. A balanced approach is suggested for both the development and selection of a frit for specific sludge batches.

\section{REFERENCES}

Brown, K.G., C.M. Jantzen, and G. Ritzhaupt. 2001. Relating Liquidus Temperature to Composition for the Defense Waste Processing Facility (DWPF) Process Control, WSRC-TR-2001-00520, Westinghouse Savannah River Company, Aiken, SC.

Lambert, D.P., T.H. Lorier, D.K. Peeler, and M.E. Stone. 2001. Melt Rate Improvement for DWPF MB3: Summary and Recommendations (U), WSRC-TR-2001-00148, Westinghouse Savannah River Company, Aiken, SC.

Miller, D.H. 2002. Summary of Results from Minimelter Run with Macrobatch 3 Baseline Feed Using Frit $320(U)$, WSRC-TR-2002-00188, Westinghouse Savannah River Company, Aiken, SC.

Peeler, D.K., T.H. Lorier, D.F. Bickford, D.C. Witt, T.B. Edwards, K.G. Brown, I.A Reamer, R.J. Workman, and J.D. Vienna. 2001. Melt Rate Improvement for DWPF MB3: Frit Development and Model Assessment (U), WSRC-TR-2001-00131, Westinghouse Savannah River Company, Aiken, SC.

Stone, M.E., and J.E. Josephs. 2001. Melt Rate Improvement for DWPF MB3: Melt Rate Furnace Testing $(U)$, WSRC-TR-2001-00146, Westinghouse Savannah River Company, Aiken, SC. 
Immobilization Technology Section

WSRC-TR-2002-00344

Savannah River Technology Center

Westinghouse Savannah River Company

Stone, M.E., and D.P. Lambert. 2001. Melt Rate Improvement for MB3: Feed Preparation, WSRC-TR2001-00126, Westinghouse Savannah River Company, Aiken, SC.

Westinghouse Savannah River Company (WSRC). 2001. Savannah River Site High Level Waste System Plan (HLW), HLW-2001-00040, Revision 12. Aiken, SC. 